\title{
PEMIKIRAN PENDIDIKAN ISLAM: Telaah Tematik Konsep Manajemen Pendidikan Dalam Al-Qur'an
}

\author{
Muslim \\ Sekolah Tinggi Ilmu al-Quran (STIQ) Bima \\ Email:muslimstiqbima@gmail.com
}

\begin{abstract}
Abstrak
Al-Qur'an Al-Karim mengandung mukjizat yang luar biasa baik dilihat dari segi kebahasaan, isyarat ilmiah dan pemberitaan gaib. Kemukjizatan al-Qur'an tdak dibatasi oleh ruang dan waktu serta zaman, berlaku sepanjang waktu sebagai pedoman dan petunjuk bagi umat manusia. Ajaran dan informasinya yang disampaikan al-Qur'an mencakup keseluruhan alam semesta, termasuk aspekaspek kebutuhan manusia didunia dan diakhirat. Salah satu bagian yang tidak terlepas dari kebutuhan manusia adalah pendidikan, maka orientasi pelaksanaan pendidikan harus merujuk kepada al-Qura'an al-Karim baik dari segi konsep maupun implementasi pelaksanaannya sehingga terwujud proses pendidikan yang memiliki nilai-nilai ketuhanan dan kepribadian ynag suci. Untuk mewujudkan pelaksanaan pendidikan yang bermutu, perlu cara-cara pengelolaan yang terukur, efektif, dan efisien, sehingga akan tercapai keberhasilan pendidikan. Oleh karena itu, konsep yang menghendaki demikian perlu penerapan konsep manajemen sebagai alat pencapaian keberhasilan pendidikan.
\end{abstract}

Kata Kunci: Pendidikan Islam, Manajemen, Al-Qur'an

\section{Pendahuluan}

Oecara teoritis bahwasannya konsep manajemen dipahami sebagai alat pencapaian, maka manajemen mencakup pada wilayah seluruh aspek kehidupan manusia. Salah satu yang paling kecil kita ambil contoh dalam aktifitas organ (anggota tubuh) manusia, semua anggota tubuh melakukan tugas masing-masing yang dikendalikan oleh pikiran dan hati. Hati dan pikiran merupakan manajer (pengatur dan pemimpin) sedangkan anggota tubuh yang lain adalah yang diatur (bawahan). Begitu juga masalah pendidikan. Pendidikan merupakan sebuah sistem. ${ }^{1}$ Sehingga pengelolaan pendidikan harus pun mengacu pada system manajerial yang baik. Ramayulis mengutip pendapat Made Pidarta mengatakan bahwa substansi manajemen pengelolaan pendidikan diutamakan pada sapek istitusi (lembaga), structural, teknik, personalia, informasi dan lingkungan atau masyarakat, ${ }^{2}$

\footnotetext{
${ }^{1}$ Sistem yang dimaksudnmencakup pengelolaan komponen-komponen yang antara satu dengan yang lainnya saling berkaitan, antara lain: kurikulum, sarana prasarana, metode pengajaran, evaluasi, dan pendanaan, Sudirman dkk, Ilmu Pendidikan, (Jakarta, Mutiara, 1986), 65.

${ }^{2}$ Ramayulis, Ilmu Pendidikan Islam, (Jakarta, Kalam Mulia, 2002), 373
} 
sehingga harapan masyarakat untuk mendapatkan pendidikan dapat tercapai dalam membentuk kepribadian anak-anak mereka.

Kata manajemen dalam bahasa Inggris berasal dari kata management berakar kata kerja to manage yang berarti mengurus, mengatur, mengelola dan melaksanakan. ${ }^{3}$ Mengutip pendapatnya Ramayulis, makna tersebut dapat dipahami dengan pengelolaan, ketatalaksanaan, atau pimpinan. ${ }^{4}$ Senada dengan pernyataan di atas, Dasrijal Dahlan mengemukakan bahwa kata manajemen yang berasalkan to manage bersinonim dengan kata to hand (mengurus), to control (memeriksa), to guide (memimpin). ${ }^{5}$ Berangkat dari kata di atas bahwa manajemen dapat dipahami dengan segala pekerjaan yang berhubungan dengan pengurusan, pengendalian, pemimpin atau pembimbing pada setiap usaha yang berkaitan dengan urusan bersama untuk mencapai hasil yang diharapkan.Dalam bahasa Arab kata managemen sepadan dengan kata dabbara (mengatur), nadzoma (mengorganisir/memimpin). ${ }^{6}$ Lalu bagaimana dalam al-Qur'an, apakah ada ayat yang membahas konsep manajemen pendidikan, ataukah ada isyarat ayat tentang manajemen, sehingga kita bisa memberikan penjelasan terhadap pembahasan dimaksud. Pada pernyataan yang terakhir inilah yang akan dicoba untuk memahaminya. Dalam al-Qur'an memang tidak secara khusus ada ayat yang menunjukan secara langsung tentang manajemen, tetapi kata-kata sustansial secara eksplisit tentang penciptaan alam raya beserta penataannya serta ungkapan mengatur, memelihara dan mengawasi sering dijumpai dalam kaitannya dengan Allah SWT., mengurus, mengatur tata laksana alam raya dan mengatur kebutuhan manusia.

\section{Konsep Dasar Manajemen Dalam al-Qur'an}

\section{Kelompok Ayat Tentang Penciptaan Alam Raya}

a. Surah Al-Jasiyah ayat 5

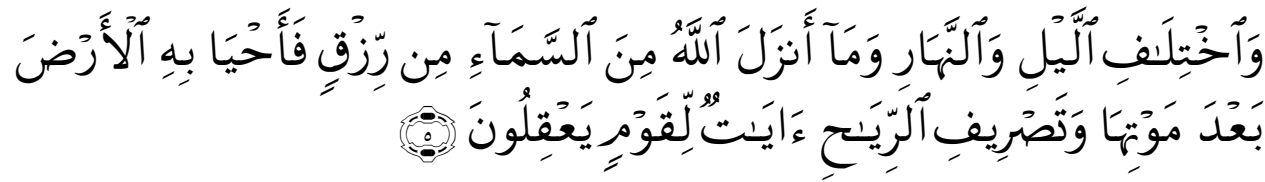

"Dan pada pergantian malam dan siang dan hujan yang diturunkan Allah dari langit lalu dihidupkan-Nya dengan air hujan itu bumi sesudah

${ }^{3}$ Jhon M. Echols Dan Hasan Shadily, Kamus Inggris-Indonesia, (Jakarta, Gramedia, 1993), 362

${ }^{4}$ Ramayulis, Op.cit. h. 371

${ }^{5}$ Dasrizal Dahlan Dan Jusmawati, Administrasi Dan Manajemen Perspektif Islam, (Padang, The Minangkabau Foundation, 2006), h. 22

${ }^{6}$ Atabik Ali Dan A Zuhdi Mudhlor, Kamus Kontemporer Arab-Indonesia, (Yogyakarta, Multi Karya Grafika, 1986), 879 
matinya; dan pada perkisaran angin terdapat tanda-tanda (kekuasaan Allah) bagi kaum yang berakal".

b. Surah al-Hijir ayat $16-17$ dan 22

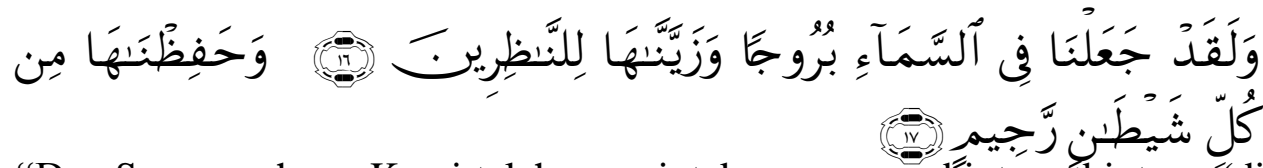

"Dan Sesungguhnya Kami telah menciptakan gugusan bintang-bintang'(di langit) dan Kami telah menghiasi langit itu bagi orang-orang yang memandang (Nya). Dan Kami menjaganya dari tiap-tiap syaitan yang terkutuk".
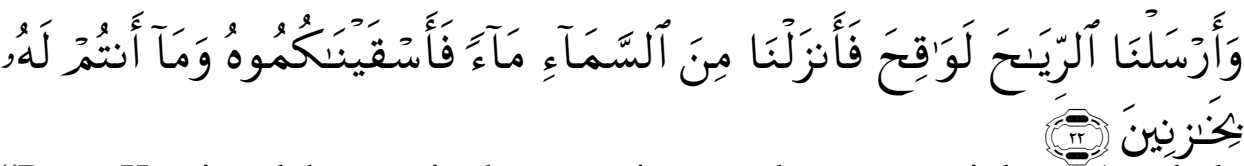

"Dan Kami telah meniupkan angin untuk mengawinkan (tumbuhtumbuhan) dan Kami turunkan hujan dari langit, lalu Kami beri minum kamu dengan air itu, dan sekali-kali bukanlah kamu yang menyimpannya.

c. Surah an-Nahal ayat 79

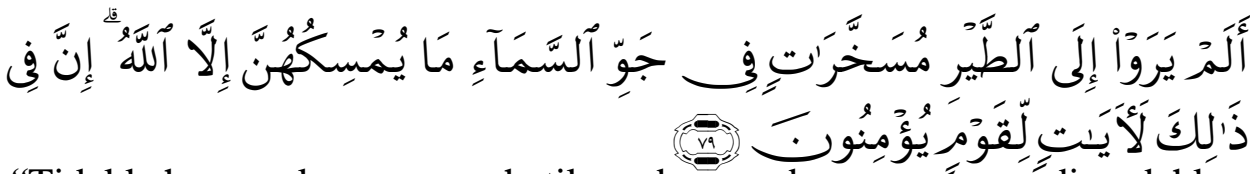

“Tidakkah mereka memperhatikan burung-burung ýang dimudahkan terbang diangkasa bebas. tidak ada yang menahannya selain daripada Allah. Sesungguhnya pada yang demikian itu benar-benar terdapat tandatanda (kebesaran Tuhan) bagi orang-orang yang beriman”.

d. Surah al-Angkabut ayat 63

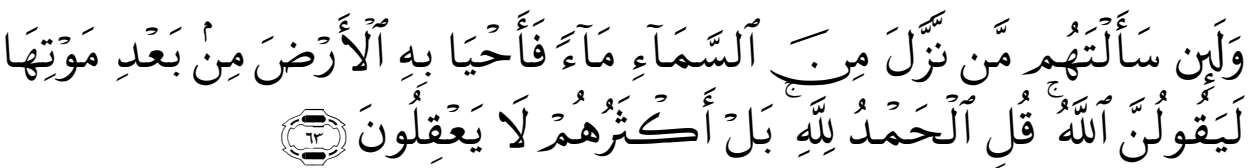

"Dan Sesungguhnya jika kamu menanyakan kepada mereka: "Siapakah yang menurunkan air dari langit lalu menghidupkan dengan air itu bumi sesudah matinya?" tentu mereka akan menjawab: "Allah", Katakanlah: "Segala puji bagi Allah", tetapi kebanyakan mereka tidak memahami(nya)".

Pada ayat yang telah dikemukakan di atas, bahwa gambaran alam yang begitu tertata rapi dan teratur baik pada pengaturan siang dan malam, hujan yang diturunkan, angin yang ditiupkan, itu semua adalah merupakan hasil ciptaan Allah sebagai pencipta sekaligus mengendalikan semua ciptaannya (pengaturan siang dan malam, hujan yang diturunkan sesuai kebutuhan makhluknya dengan teratur, tertata rapid an jauh dari kesalahan. Memakna hasil ciptaan Allah SWT., terhadap seluruh perangkat 
alam maka Allah sebagai pencipta semuanya memberikan kesan keharmonisan dan keseimbangan antara benda-benda samawi, baik secara sendiri-sendiri maupun dalam kaitannya dengan seluruh jagad raya. Hal ini, menunjukan adanya pengorganisasian dan kedisiplinan yang amat mengagumkan dalam jagad raya, semuanya mengungkapkan adanya kebenaran yang paling asasi dari yang mengendalikan alam raya. $^{7}$

At-Thibrisi menjelaskan kalimat wakhtilafi laila wa an-nahar merupakan proses pergantian waktu, baik siang ataupun walam berjalan terus menerus sampai waktu yang ditentukan sesuai peredaranya. ${ }^{8}$ Ini menunjukan bahwa pengendalian alam raya diatur dan dijalankan dengan tata pengaturan yang baik hingga batas waktu yang ditentukan tanpa keluar dari jalur dan tempat peredarannya. M. Quraish Shihab menjelaskan, maksud ayat 16 surah al-Hijir bahwa keberadaan angin untuk mengawinkan (tumbuh-tumbuhan) dan diturunkan hujan dari langit. Lalu kami beri minum kamu dengan air itu adalah merupakan ciptaan Allah SWT dan semua yang telah diciptakan itu semuanya tunduk kepada kehendak-Nya. ${ }^{9}$ Lebih lanjut pada ayat 17 surah al-Hijir, M. Quraish Shihab memberikan penjelasan bahwa kata antum lahu bikhozinin dapat berarti bahwa allah berkuasa atas tempat penyimpanan hujuan dilangit itu, mengelola turunnya serta kadar air yang turun bukanlah berada dalam kewenangan manusia. ${ }^{10}$

Berdasarkan penjelasan diatas bahwa, Allah SWT., memiliki kewenangan penuh terhadap semua ciptaan-Nya sekaligus menjelaskan bahwa hujan tidaklah sekaligus diturunkan, tetapi diatur dan diberikan sesuai dengan kebutuhan manusia dan makhluk yang lain. Bentuk pengaturan seperti ini dapat menjadi isyarat adanya pelaksanaan pendidikan dengan konsep manajemen dengan peradigma bahwa pengelola utama (pemimpin) dalam pendidikan memiliki kewenangan untuk mengatur dan menargetkan hasil pencapaian pendidikan sesuai dengan visi dan misi dan tujuan pendidikan. Pada ayat 19 surah an-Nahal lebih lanjut M. Quraish Shihab menjelaskan bahwa pokok pembicaraan ayat diatas betul-betul menyuruh manusia memperhatikan dengan ungkapan "tidaklah mereka memperhatikan burung-burung yang dimudahkan terbang diangkasa bebas, tidak ada yang memahaminya selain dari pada Allah" merupakan salah satu bukti kekuasaan allah SWT., dan Dia yang

${ }^{7}$ Afzalur Rahman, Qur'anic Science, Diterjemahkan oleh Arifin, Al-Qur'an Sumber Ilmu Pengetahuan, (Jakarta, Rineka Cipta, 2000), 58

${ }^{8}$ Abi Ali Fadhli Bin Hasan At-Thibrisi, Majmu'ul Bayan Fi Tafsir Al-Qur'an, Juz 9, (Dar ElMarefah), 107

${ }_{9}^{9}$ M. Quraish Shihab, Tafsir Al-Misbah: Pesan, Kesan Dan Keserasian Al-Qur'an, Jilid 7, (Jakarta, Lentera Hati, 2002), 104

${ }^{10} \mathrm{Ibid}, 114$. 
memberikan potensi burung untuk bisa terbang. ${ }^{11}$ Surah al-Anbiya ayat 16 lebih lanjut ia menguaraikan "tidaklah kami menciptakan langit dan bumi dan segala usaha yang ada diantara keduannya dengan tata aturan yang demikian rapi, indah dan harmonis dengan bermain-main yakni tanpa arah yang tujuan yang benar, tetapi itu semua kami ciptakan untuk membuktikan keesaan dan ekuasaan kami serta untuk kepentingan makhluk-makhluk kami. ${ }^{12}$

Dengan memperhatikan ayat di atas ada beberapa penjelasannya, mengandung maksud bahwa, Allah SWT sebagai penguasa, menguasai seluruh pergerakan yang terdapat dalam kehidupan makhluk-Nya, menentukan kadar dan ketentuan sesuai dengan kebutuhan makhluk, mengatur semua kepentingan dan urusan makhluk dengan adil. Maka memaknai ayat diatas dihubungkan dengan manajemen pendidikan merupakan sebuah relasi, hubungan dan pengaruh antara pemimpin sebagai pengawas terhadap semua yang berhubungan dengan pelaksanaan pendidikan sekaligus mengatur urusan sesuai dengan tugas dan fungsi masing-masing bekerja sesuai dengan tugas pokok yang telah digariskan. pemimpin sebagai top leader merumuskan kebijakan dan yang dipimpin (dikelolanya) sebagai bawahan yang menjalankan tugas-tugas. Kepemimpinan ini bisa berfungsi atas dasar kekuasaan pemimpin untuk mengajak, mempengaruhi dan menggerakkan orang lain guna melakukan sesuatu demi pencapaian satu tujuan tertentu. ${ }^{13}$

\section{Kelompok Ayat Tentang Pengaturan Alam}

a. Surah Yunus ayat 3

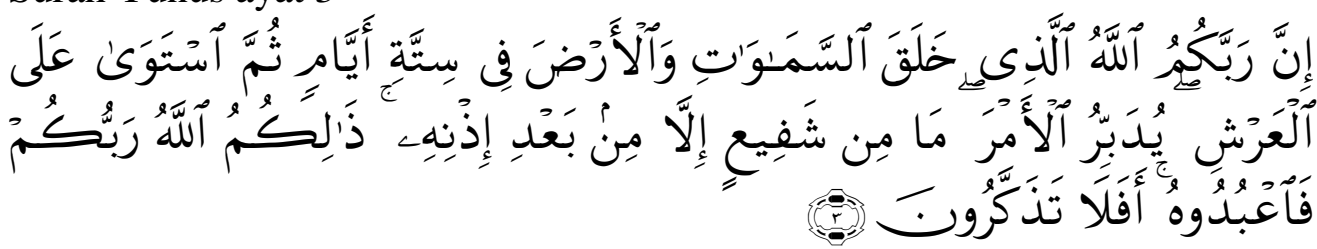

"Sesungguhnya Tuhan kamu ialah Allah yang menciptakan langit dan bumi dalam enam masa, kemudian Dia bersemayam di atas 'Arsy untuk mengatur segala urusan. tiada seorangpun yang akan memberi syafa'at kecuali sesudah ada izin-Nya. (Dzat) yang demikian Itulah Allah, Tuhan kamu, Maka sembahlah Dia. Maka Apakah kamu tidak mengambil pelajaran?".

\footnotetext{
${ }^{11}$ Ibid, Jilid 7, 306

${ }^{12}$ Ibid, 426

${ }^{13}$ Kartini Kartono, Pemimpin Dan Kepemimpinan, (Jakarta, RajaGrafindo Persada), 1998), . 5
} 
b. Surah Ar-Ra'du ayat 2

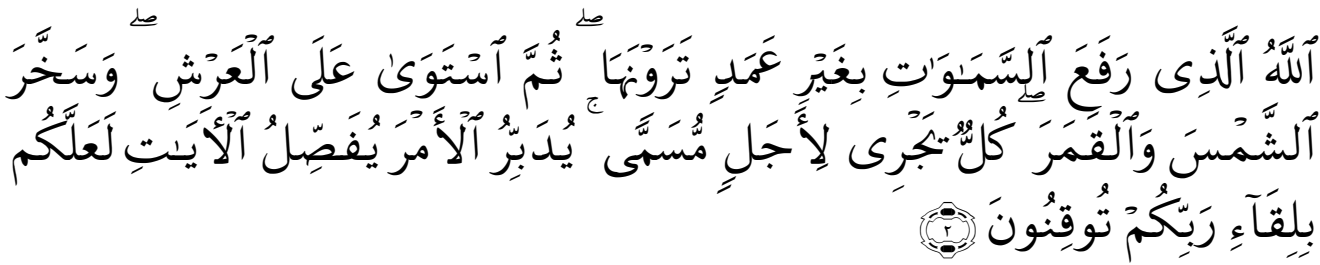

"Allah-lah yang meninggikan langit tanpa tiang (sebagaimana) yang kamu lihat, kemudian Dia bersemayam di atas 'Arasy, dan menundukkan matahari dan bulan. masing-masing beredar hingga waktu yang ditentukan. Allah mengatur urusan (makhluk-Nya), menjelaskan tanda-tanda (kebesaran-Nya), supaya kamu meyakini Pertemuan (mu) dengan Tuhanmu”.

c. Surah As-Sajadah ayat 5-6

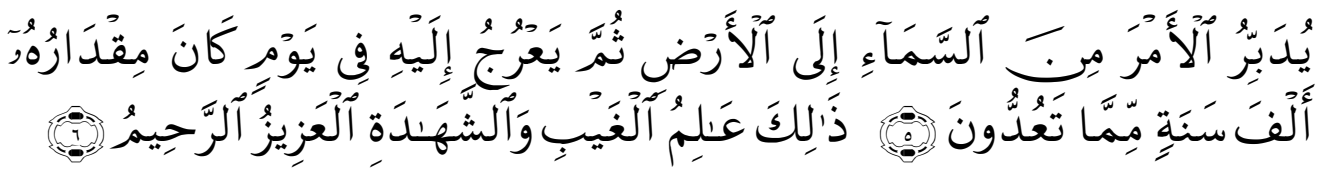

"Dia mengatur urusan dari langit ke bumi, kemudian (urusan) itu naik kepadanya dalam satu hari yang kadarnya adalah seribu tahun menurut perhitunganmu. Yang demikian itu ialah Tuhan yang mengetahui yang ghaib dan yang nyata, yang Maha Perkasa lagi Maha Penyayang”.

Semua ayat menggunakan kata yudabbirul al-amar yang berarti secara sederhana adalah mengatur urusan. Kata dabbara bererti di belakang/diakhir sesuatu. Memaknai kata yudabbiru M. Quraish Shihab ${ }^{14}$, menjelaskan bahwa orang yang yudabbiru atau melakukan penabdiran, bukan saja mengadakan sesuatu, tetapi juga memperhatikan apa yang akan terjadi sesudah dibelakang pandangan itu. Ia harus memperhitungkan bagaimana akhir dan kesudahan serta dampak yang alkan dating dari apa yang diadakan itu. Penadbiran menuntut agar mewujudkan dengan baik dan benar apa yang diadakan itu sehingga ia dapat berfungsi untuk masa kini dan masa mendatang serta tidak melahirkan dampak negativ.

Pernyataan di atas menunjukan bahwa semua aktifitas yang dibuat semestinya harus memperhatikan bagaimana melakukan dan menjalaninya sehingga hasil dari pekerjaan itu dapat memberikan manfaat baik. Pada konsep yang sangat jelas kata yudabbirul al-amra, Ahmad al-Syawi

${ }^{14}$ Walaupun pada dasarnya M. Quraish Shihab memberikan penjelasan bahwa kata dabbara pada Surah ar-Ra'du ayat 2 berarti mengatur yakni Allah SWT mengatur alam raya yang semua dilakukan-Nya dengan memperhatikan segala sesuatu, serta mengaturnya sehingga tidak ada dampak negative yang akan terjadi pada segala sesuatu akibat penciptaan dan pengaturannya. M. Qurais Shihab, Op.cit., 551 
menafsirkan sebagaimana dikutip oleh Ramayulis: bahwa Allah adalah pengatur alam (manajer). ${ }^{15} \mathrm{Hal}$ ini dibuktikan dengan alam raya sangatlah teratur adanya sebagai tanda-tanda kebesaran Allah SWT dan sekaligus mengelolanya dengan baik. Maka manusia telah dijadikan Allah SWT sebagai khalifah dibumi, manusia harus mengatur dan mengelolanya dengan sebaikbaiknya sebagaimana Allah SWT mengatur alam raya ini.

Manajemen sebagai konsep sebagaimana pada uraian di atas adalah merupakan sebuah proses pengaturan pekerjaan dengan tugas-tugas yang mengaarahkan usaha ke arah tujuan untuk mencapai hasil yang dikehendaki. ${ }^{16}$ Pengaturan dan hasil merupakan satu kesatuan yang tidak dapat dipisahkan, maka manajemen pendidikan menghendaki agar segala yang menjadi perioritas pekerjaan dapat memberikan hasil sesuai dengan tujuan pencapaiannya. Hasil pencapaian pada pendidikan dalam al-Qur'an tentunya agar manusia memiliki kompetensi dan kreatifitas yang dapat meningkatkan kualitas keimanan dan ketakwaan kepaada Allah SWT.

\section{Analisis Ayat Terhadap Implementasi Manajemen Pendidikan.}

Al-Qur'an diturunkan oleh Allah SWT., tidak saja dilantunkan dan dibaca dengan bagus, tetapi yang perlu juga dilakukan adalah mengkaji makna-maknanya, menelaah dan menyingkap isi kandungannya, sehingga hasil dari pengkajian didalamnya menjadi pedoman, petunjuk dan konsep-konsep dalam berbagai persoalan dan bidang kehidupan manusai. Mengkaji ayat-ayat al-Qur'an berarti berupaya memahami maksud dan tujuannya, sehingga dalam kehidupan manusia memiliki landasan hidup berdasarkan nilai-nilai dalam aal-Qur'aan. Orientasi akhir dari seluruh proses kehidupan manusia adalaah mencari kebaahagiaan dunia dan akhirat.

Memahami ayat-ayat di atas sebagai rujukan dalam tata kelola baaik dalam kehidupan manusia maupun proses-proses pelaksanaan pendidikan khususnya manajemen pendidikan, paling tidak terdapat beberapa makna penting. Mengutip pendapatnya Abuddin Nata, antara lain: pertama, adanya kata yudabbiru yang berarti mengurus, memanej, mengarahkan, membina, merencanakan, melaksanakan, dan mengawasi. Kedua, adanya obyek atau berbagai hal yang diatur, diurus, dibina dan seterusnya yang dalam ayat tersebut diwakili oleh pengaturan siang dan malam yang mengacu kepada ppengaturan waktu untuk melakukan pekerjaan. Ketiga, adanya unsure yang mengatur, memanej dan seterusnya yang dalam hal ini adalah Allah

\footnotetext{
${ }^{15}$ Ramayulis, Op.cit, 237

${ }^{16}$ Made Pidarta, Manajemen Pendidikan Indonesia, (Jakarta, Rineka Cipta, 2004), h. 3
} 
SWT. ${ }^{17}$ Lebih lanjut Abuddin Nata menjelaskan, bahwa maaksud dari poin penting yang dikemukakan di atas adalah bahwa Allah SWT telah menampilkan ddirinya sebagai administrator atau manajer yang handal, mengingkat apa yang diatur dan dimanaj tersebut jumlahnya tidak terhitung banyaknya. ${ }^{18}$

Dengan demikian, dalam al-Qur'aan memberikan inti kejelasan bahwa semua yang ada dilangit dan dibumi adalah milik Allah. Dia yang telah menciptakan, mengatur dan mengawasi semua ciptaannya. Hal ini, memberikan isyarat bahwa dalam semua lini kehidupan manusia harus mengambil ibrah, contoh dan hikmah terhadap semua yang telaah dijelaskan dalam al-Qur'an agar proses pencapaian hajatan manusia berjalan sesuai dengan baik dan memiliki hasil yang baik, sebagaimana Allaah SWT. Telah menunjukkan tanda-tanda kekuasaan-Nya.

Al-Qur'an memberikan isyarat tentang perlunya meniru sifat-sifat Allah SWT., yang menunjukan tentang perlunyaa melaksanakan fungsi pengaturan alam semesta sebagaimana yang terdapat dalam asma al-Husna antara lain: sifat; alQudrah (otoritas atau power untuk mengambil keputusan), al-Iradah (hak mengaambil inisiatif), al-Ilm (memiliki wawasan atau konsep), serta sifat-sifat yang lain seperti kompetensi moral al-Rauf (Maha Belas Kasi), al-Waduud (maha mencintai), afuw (maha mengampunkan), as-Salam (maha menyelamatkan) dan Bar (maha baik). ${ }^{19}$ Inplikasi terhadap ssifat-sifat diatas menjadi pola dan dasar terhadap pelaksanaan manajemen baik fungsi-fungsi manajer seperti: planning (pengorganisasian), organizing (pengaturan), actuating (pelaksanaan), controlling (pengawasan), evaluating (penilaian) maupun prinsip manajemen seperti prinsip berorientasi pada pencapaian mutu, prinsip standar mutu, prinsip kepercayaan untuk bekerja sama.

Sifat-sifat Allah SWT., di atas menunjukan bahwa, sebagai manajer Allah memiliki kemampuan yang terkait dengan kompetensi akademik dan seluruh sifatsifat tersebut sangat dibutuhkan dalam melaksanakan tugas sebagai administrator dan manajer. Dengan demikian, al-Qur'an al-Karim dengan sangat meyekinkan telah menampilkan allah sebagai manajer dan administrator Yang Maha Handal. Bukti yang ditujukan kepada manusia bahwa bahwa dalam al-Qur'an selain adanya isyarat yang cukup kuat tentang adanya konsep manajemen juga menghendaki agar manusia

${ }^{17}$ Abudin Nata, Pendidikan Dalam Perspektif Al-Qur'an, (Jakarta, Proyek Pengadaan Buku Daras UIN Syarif Hidayatullah, 2005), 326

18 Ibid, 326

${ }^{19}$ Ibid, 328-329 
berkewajiban juga melaksanakan fungsi-fungsi manajemen dengan sebaik-baiknya. ${ }^{20}$ Mengacu kepada landasan pemahaman al-Qur'an di atas dan implikasinya terhadap proses pendidikan yang dikelola berdasarkan pola manajemen maka proses pengelolaan pendidikaan tentunya mengarah kepada isyarat-isyarat yang Allah telah tunjukkan dalam penciptaan dan pengaturan serta pemeliharaan-Nya. Dari isyarat tersebut maka muncullah beberapa implikasi terhadap makna manajemen pendidikaan sebagaimana yang dikemukakan oleh para ahli antara lain, Husain Muhdar yang dikutip oleh Nawwal al-Thuwwairuqi mendefinisikan manajemen pendidikan merupakan "segenap upaya, kemampuan dan kegiatan yang dikerahkan dalam rangka mewujudkan tujuaan-tujuan pendidikan secara sefektif dan berkembang. ${ }^{21}$

Sedangkan Nawwal al-Thuwwairaqi mengatakan bahwa manajemen pendidikan adalah sejimlah upaya yang terkoordinir, yang dikerahkan oleh manajemen yang berwenang dalam lingkup pendidikan dalam rangka mewujudkan tujuan-tujuan yang telah ditetapkan sesuai dengan arahan-arahan menajemen pendidikan dan rencana-rencananya. Sementara Shahal Mustafa memahami manajemen pendidikan disebut dengan amal jama'I yaitu merupakan sebuah proses penyatuan pergerakan organisasi/lembaga dan individu pada ssuatu pekerjaan dilakukan untuk mencapai keberhasilan yang sempurna. ${ }^{22}$

Berdasarkan uraian diatas, pelaksanaan manajemen pendidikan tidak dapat dipisahkan dengan adanya instrument manajemen pendidikan pada proses penerapan prinsip dan teori manajemen dalam pengelolaan kegiatan pendidikan untuk mengefektifkan pencapaian tujuan pendidikan. Diantara prinsip manajemen pendidikan adalah adanya: pertama, koordinasi, kedua, integrasi ketiga singkronisasi. $^{23}$ Prinsip koordinasi adalah usaha bersama untuk menghimpun sekaligus mengarahkan kegiatan-kegiatan yang dilakukan, semuaa sarana dalam organisasi pendidikan kepada tujuan dan hasil pendidikan. System pencapaian berdasarkan koordinasi yang baik akan menghasilkan kekuatan dalam pencapaian tujuan. Dalam surah as-Shaff ayat 4 Allah berfirman:

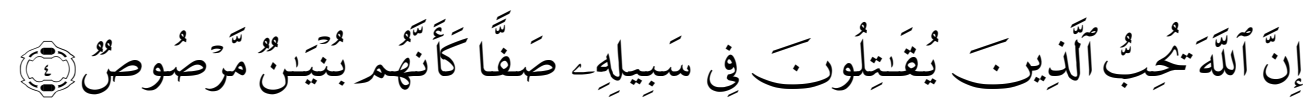

${ }^{20}$ Nawwal Ath-Thuwwairuqi, al-Alaqaat Al-Insaniyah Fi As-Sirah an-Nabawiyah Wa Thathbiiqaatuha Fi al-Idaarah al-Madrasiyah, diterjemahkan oleh Asmunir, Sekolah Unggulan Berbasis Sirah Nabawiyah, (Jakarta, Darul Falah, 2004), 31

${ }^{21}$ Ibid, 32

${ }^{22} \mathrm{Ibid}, 32$

${ }^{23}$ Rosniati Hakim, Manajemen Guru MDA Dan Implikasinya Terhadap Peningkatan Kualitas Pembelajaran, (Padang, Imam Bonjol Press, 2013), 20 
"Sesungguhnya Allah menyukai orang yang berperang dijalan-Nya dalam barisan yang teratur seakan-akan mereka seperti suatu bangunan yang tersusun kokoh"

Maksud dari kata as-Shaff paada ayat di atas menurut al-Qurtubi adalah sebagai isyarat menyeluruh untuk merapatkan baarisan (yasuffuna anfusahum shaffan). ${ }^{24}$ Merapatkan barisan atau yang biasa dengan organisasi, agar perkumpulan umat atau anggota jaamaah punya system yang teratur supaya terdapat peraturan untuk mencapai tujuan bersama. Tujuan yang dimaksudkan agar segala pekerjaan terorganisir melalui struktur organisasi yang jelas dan terukur.

Integrasi adalah usaha untuk menyatukan kegiatan dari berbagai kegiatan dalam suatu organisasi pendidikan sehingga merupakan suatu kebulatan pikiran maupun tindakan ke suatu tujuan. Sedangkan sinkronasasi adalah usaha untuk menyelaraskan kegiatan dari berbagai unit guna tercapainya keharmonisasn tindakan dalam mencapai tujuan. Orientasi dari pencapaian pelaksanaan system pendidikan tergantung pada sungguh dan matangnya implementasi teori manajemen pada pelaksanaan pendidikan. Sebuah lembaga pendidikan yang baik dan unggul adalah lembaga pendidikan yang memiliki budaya mutu. Ada beberapa teori yang memberikan konsep dan rumusan terhadap pengelolaan pendidikan sebagai standar mutu untuk mencapai tujuan pendidikan yaitu antara lain; total quality manajemen/manajemen mutu terpadu (TQM), quality manajemen system/system manajemen mutu (QMS). Walaupun sebenarnya konsep QTM dpakai pada dunia bisnis, tetapi dekade akhir-akhir ini sudah mulai dipakai pada lembaga pendidikan dalam meningkatkan mutu dan kualitas pendidikan dengan diterapkannya akreditasi sebagai salah satu pelaksanaan quality assurance sedangkan quality control disamakan dengan ujian akhir nasional (UAN).

Secara keseluruhan implementasi manajemen pendidikan harus bermuara pada unsur-unsur penting pengelolaan pendidikan sebagai implementasi peningkatan mutu pendidikan antara lain:

a. Manajemen kurikulum dan pengajaran

b. Manajemen tenaga kependidikan

c. Manajemen kesiswaan

d. Manajemen keuangan dan pembiayaan

e. Manajemen sarana dan prasarana pendidikan

f. Manajemen hubungan sekolah dengan masyarakat

g. Manajemen layanan khusus. ${ }^{25}$

\footnotetext{
${ }^{24} \mathrm{Abu}$ Abdullah Muhammad Bin Ahmad Al-Anshari Al-Qurthubi, Al-Jami' Al-Ahkam AlQur'an, (Beirut, Darul Al-Kitab Al-Islamiyah, 1995), 54

${ }^{25}$ E. Mulyasa, Manajemen Berbasis Sekolah: Konsep, Strategis Dan Implementasi, (Jakarta, Rosda Karya, 2003), 39
} 
Berdasarkan uraian di atas bahwa, isyarat ayat al-Qur'an yang menerangkan tentang fenomena dan pergerakan alam menjadi bahan fikiran untuk dijadikan landasan dalam memahami makna kehidupan. Pendidikan merupakan bagian terpenting dalam kehidupan manusia. Oleh karena itu, memahami pendidikan juga harus diiringi dengan pengetahuan tentang cara melaksanakan pendidikan (manajemen pendidikan).

Manajemen sebagai salah satu disiplin ilmu yang bersifat praktis memegang peran penting dalam aktifitas pendidikan. Pendidikan tidak bisa berjalan sesuai dengan sasaran dan tujuan yang dharapkan jika tidak menggunakan jasa manajemen. Adanya manajemen pendidikan memberikan arah pada pelaksanaan pendidikan sesuai dengan yang diharapkan. Isyarat al-Qur'an tentang Allah sebagai pencipta dan pengatur alam dan pengaturan-Nya sesuai kadar ketentuan yang dibituhkan oleh makhluknya dengan harmonis tanpa ada kesalahan. Maka dalam manajemen pendidikan pun menisyaratkan agar pengelolaan pendidikan diatur dengan baik tanpa ada kesalahan dan penyimpangan.

\section{Fungsi Manajemen Pendidikan Dalam Al-Qur'an}

Peranan manajemen dan aplikasinya, sangat ditentukan oleh fungsi-fungsi manajemen. Fungsi manajemen inilah yang menjadi inti dari manajemen itu sendiri. ${ }^{26}$ Manajemen adalah suatu bentuk kerja dan dalam melakukan pekerjaannya manajer harus melaksanakan kegiatan-kegiatan tertentu, yang disebut fungsi manajemen. Untuk lebih memahami fungsi-fungsi manajemen dimaksudkan diatas, selanjutnya akan diuraikan sebagai berikut.

\section{a. Perencanaan (Planning)}

Perencanaan merupakan aktifitas utama yang dilakukan oleh setiap manajer, karena rencana yang dibuat akan menggambarkan sasaran dan prosedur yang terbaik untuk mencapai sasaran tersebut. Merencanakan suatu kegiatan merupakan tindakan awal sebagai pengakuan bahwa suatu pekerjaan tidak semata-mata ditentukan sendiri keberhasilannya, namun banyak factor lain yang harus dipersiapkan untuk mendukung keberhasilan tersebut. Sebagai bentuk persiapan pelaksanaan suatu urusan. Dalam al-Qur'an manusia dianjurkan untuk memperhatikan segala proses, baik jangka pendek maupun jangka panjang untuk memberikan peluang dan hasil yang dicapai. Allah berfirman surah al-Hasyar ayat 18 sebagai berikut:

\footnotetext{
${ }^{26}$ Ramayulis, Op.cit., 378
} 


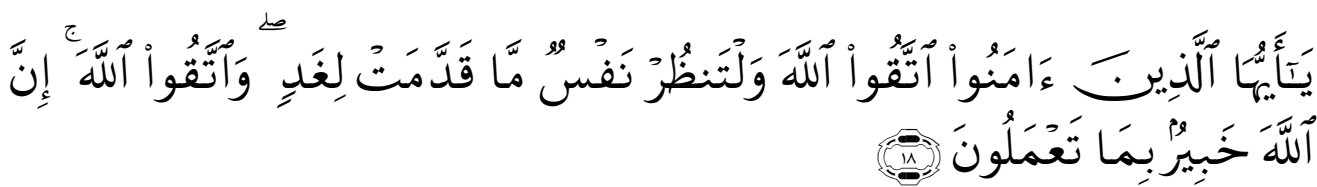

"Hai orang-orang yang beriman, bertakwalah kepada Alláh dan hendaklah Setiap diri memperhatikan apa yang telah diperbuatnya untuk hari esok (akhirat); dan bertakwalah kepada Allah, Sesungguhnya Allah Maha mengetahui apa yang kamu kerjakan".

M. Quraish Shihab menjelaskan, bahwa kata tuqaddima dikedepankan, digunakan dalam arti amal-amal yang dilakukan untuk meraih manfaat dimasa yang akan datang. Lebih lanjut ia menjelaskan bahwa perintah memperhatikan apa yang telah diperhatikan untuk hari esok dengan mengutip thabathaba'in adalah sebagai perintah untuk melakukan evaluasi terhadap amal-amal (pekerjaan) yang telah dilakukan. ${ }^{27}$ Sedangkan Hasbi as-Shidiqi mengemukakan bahwa tuqaddima berarti memperhatikan urusan pekerjaan (akhirat) yang dapat memberikan manfaat pada masa-masa yang akan datang. ${ }^{28}$ Menurut Muhammad Ali As-Shabuni, yang dimaksud dengan "wa al-tandzuru nafsun maa qaddamat li ghadi” adalah hendaknya masing-masing individu memperhatikan amal-amal shaleh apa yang diperbuat untuk menghadapi hari kiamat. ${ }^{29}$ Ayat ini memberikan pesan kepada orang-orang yang beriman untuk memikirkan masa depan. Dalam bahasa manajemen, perkiraan masa depan yang dituangkan dalam konsep yang jelas dan sistematis ini disebut perencanaan (planning). Perencanaan ini menjadi sangat penting karena berfungsi sebagai pengarah bagi kegiatan, target-target dan hasil-hasilnya dimasa depan sehingga apapun kegiatan yang dilakukan dapat berjalan dengan tertib.

Berdasarkan ayat datas, memberikan perhatian kepada manusia khusus umat Islam yang beriman agar setiap melakukan suatu urusan harus dikedepankan perencanaan yang matang agar semua urusan member manfaat yang baik pada masa-masa yang akan datang. Perencanaan yang baik akan melahirkan kebaikan dan kebaikan dari usaha yang telah direncanakan dengan matang juga akan menghasilkan kesuksesan dan dari kesuksesan yang

${ }^{27}$ M. Quraish Shihab, Tafsir Al-Misbah: Pesan, Kesan, Dan Keserasian al-Qur'an, (Jakarta, Lentera Hati, 2004, 129

${ }^{28}$ Teungku Muhammad Hasbi Ash-Shiddiqy, Tafsir Al-Qur'anul Majid, (Semarang, Pustaka Rizki Putra, 1995, 432

${ }^{29}$ Muhammad Ali As-Shabuni, Shafwat At-Tafsir, (Beirut, Dar El-Fikri), 355 
didapatkan akan memberikan kebahagiaan. Hal ini dapat dipahami dari firman Allah SWT. Surah al-Baqarah ayat 201 sebagai berikut:

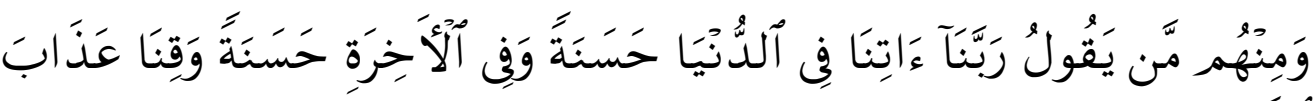

"Dan di antara mereka ada orang yang bendoa: "Ya Tuhan Kami, bérilah Kami kebaikan di dunia dan kebaikan di akhirat dan peliharalah Kami dari siksa neraka".

Stimulan yang diberikan al-Qur'an dengan memperhatikan apa yang akan diperbuat untuk hari esok yang perlu dilakukan adalah perbuatan yang baik, rapi, harus direncanakan dan dirumuskan sesuai dengan kebutuhan yang akan dicapai baik perorangan maupun organisasi. Kata hasanah mengandung arti yang baik, bahkan bukan saja didunia tetapi juga memohon hasanah di akhirat. ${ }^{30}$ Arah kebijakan yang akan dilakukan mengarah kepada hasil yang berdampak pada kebaikan dan ketakwaan. Hal sebagaimana firman Allah SWT. Dalam surah al-Mujadalah ayat 9 sebagai berikut:

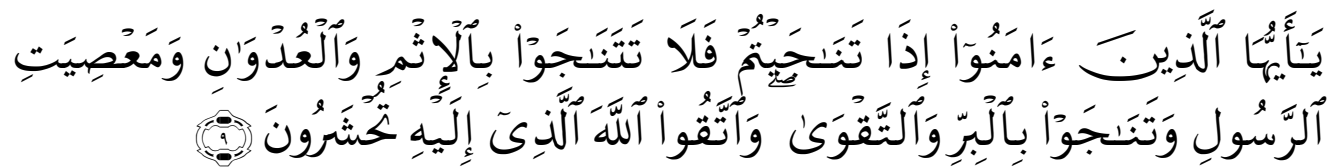
"Hai orang-orang beriman, apabila kamu Mengadakan pémbicaraan rahasia, janganlah kamu membicarakan tentang membuat dosa, permusuhan dan berbuat durhaka kepada rasul. dan bicarakanlah tentang membuat kebajikan dan takwa. dan bertakwalah kepada Allah yang kepada-Nya kamu akan dikembalikan".

Menurut Ramayulis bahwa dalam manajemen pendidikan perencanaan itu diarahkan meliputi:

1) Penentuan perioritas agar pelaksanaan pendidikan berjalan efektif, perioritas kebutuhan agar melibatkan seluruh konponen yang terlibat dalam proses pendidikan, masyarakat dan murid.

2) Penetapan tujuan sebagai garis pengarahan dan sebagai evaluasi terhadap pelaksanaan dan hasil pendidikan.

3) Formulasi prosedur sebagai tahap-tahap rencana tindakan

4) Penyerahan tanggung jawab kepada individu dan kelompok-kelompok kerja. ${ }^{31}$

\footnotetext{
${ }^{30}$ M. Quraish Shihab, Op.cit., Vol I, 412

${ }^{31}$ Ramayulis, Op.Cit., $379-380$
} 


\section{b. Pengorganisasian (organizing)}

Pengelolaan pendidikan berbasis manajemen menghendaki agr tujuan lembaga pendidikan menjadi kuat. Sebaik apa pun dan bagaimana pun kuatnya sebuah lenbaga membutuhkan pengorganisasian yang terkonsolidasi. Ali Bin Abi Thalib mengatakan bahwa kebenaran itu harus terorganisasi bila tidak maka akan kalah dan hancup "al-haqqu bila nidhomi yaglibuhu al-bathil bin an-nidzomi". Yulizar Yunus menggambarkan tentang pengaturan bumi dan langit oleh Allah SWT., langit sebagai atap, ${ }^{32}$ bumi disediakan sebagai tempat menetap dan kesenangan dalam batas tertentu, ${ }^{33}$ laut disediakan untuk ikan hidup dan manusia berlayar di atasnya dan udara atau angkasa disediakan untuk burung terbang dengan sayapnya dan manusia terbang dengan pesawat semata-mata agar manusia mampu memikirkan dan melaksanakan dalam hidupnya adalah sebagai isyarat betapa pengaturan itu telah terorganisir dengan rapi dan terstruktur. ${ }^{34}$ Sedangkan pengorganisasian dalam pendidikan adalah proses penentuan struktur, aktivitas, interaksi, desain struktur, wewenang, tugas secara transparan dan jelas, baik pada pekerjaan pribadi maupun kolektif. ${ }^{35}$ Sebagaiman Allah SWT berfirman dalam surah as-Sajadah ayat 5-6.

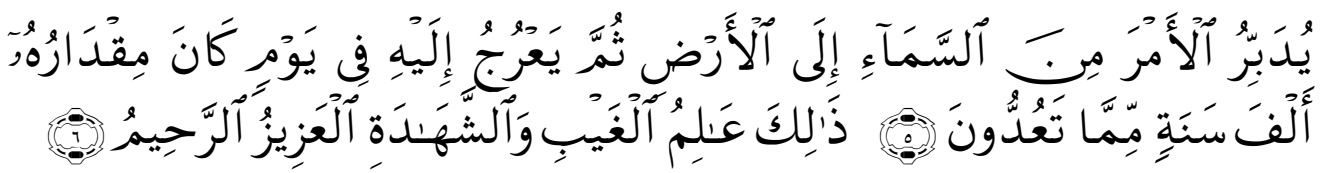

"Dia mengatur urusan dari langit ke bumi, kemudian (urusan) itu naik kepadanya dalam satu hari yang kadarnya adalah seribu tahun menurut perhitunganmu. yang demikian itu ialah Tuhan yang mengetahui yang ghaib dan yang nyata, yang Maha Perkasa lagi Maha Penyayang".

Sebuah organisasi dalam manajemen pendidikan akan berjalan dengan lancar dan sesuai dengan tujuan jika konsisten dengan prinsip -prinsip yang didesain bersamaan dengan perjalanan sebuah organisasi pendidikan. Prinsipprinsip tersebut adalah: (1) kebebasan, (2) keadilan, (3) musyawarah, (4) keluhuran manusia dan (5) transparan. ${ }^{36} \mathrm{Al}$-Qur'an menerangkan prinsip yang paling penting dalam sebuah pekerjaan harus didasari dengan amanah. Allah berfirman dalam surah an-Nisa ayat 58 sebagai berikut:

\footnotetext{
${ }^{32}$ QS. Al-Mu'min ayat 64

${ }^{33}$ QS. Al-Baqarah ayat 36

${ }^{34}$ Yulizar Yunus, Pengembangan Administrasi, Manajemen Dan Supervisi Pendidikan Islam, (Padang, Grafic Delapab Belas, 2010), 128

${ }^{35}$ Ramayulis, Op.cit., 284

${ }^{36}$ Ibid, 248
} 


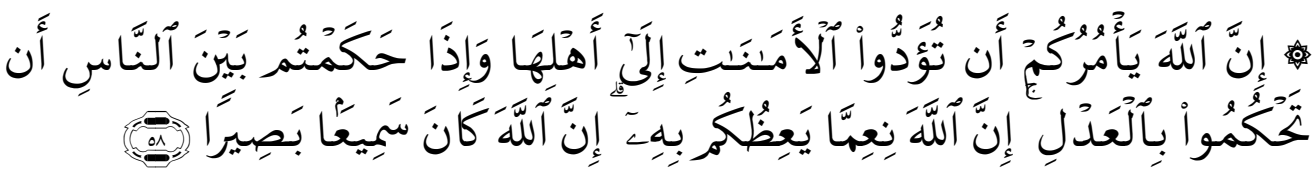

"Sesungguhnya Allah menyuruh kamu menyampaikan amanat kepada yang berhak menerimanya, dan (menyuruh kamu) apabila menetapkan hukum di antara manusia supaya kamu menetapkan dengan adil. Sesungguhnya Allah memberi pengajaran yang sebaik-baiknya kepadamu. Sesungguhnya Allah adalah Maha mendengar lagi Maha melihat”.

Amanah adalah sesuatu yang diserahkan kepada phak lain untuk dipelihara dan dikembalikan bila tiba saatnya atau bila diminta oleh pemiliknya. Amanah adalah lawan dari khianat. Seorang yang amanah tidak akan memberi kecuali kepada orang yang dinilai oleh pemberinya dapat memelihara dengan baik apa yang diberikan tersebut. Kata amanah satu rumpun dengan kata aman. Iman adalah kepercayaan sedangkan amanah adalah bagaimana melaksanakan iman itu. ${ }^{37}$ Ibnu Abbas mengatakan bahwa ayat di atas bersifat umum, maksudnya kepada orang yang memerintah dengan baik atau memiliki kewenangan untuk memerintah. ${ }^{38}$ Begitu pentingnya amanah maka, seorang yang menjalankan tugas harus dengan tingkat professional yang dimilikinya. Sebagaimana Rasulullah SAW bersabda:

Dari Abu Hurairah radiyallahu'anhu, dia berkata, "Tatkala Nabi Shalallahu 'alaihi wasallam sedang bermajelis menyampaikan pembicaraan kepada sekumpulan orang, tiba-tiba saja datang seorang Arab badui seraya mengatakan, Kapan hari kiamat itu (Wahai Rasulullah!)?" Rasulullah Shalallahu 'alaihi wasallam-pun terus meneruskan pembicaraannya, hingga sebagian orang mengatakan, 'Beliau mendengar, namun (kelihatannya) beliau tidak suka dengan apa yang ditanyakannya. Sebagian yang lain menimpali, Bukan, beliau tidak mendengarnya. Hingga tatkala beliau selesai dari pembicaraannya, beliau bertanya, Dimana orang yang aku lihat bertanya tentang Hari Kiamat tadi? dia (orang yang bertanya tadi) menjawab, Saya wahai Rasulullah! Beliau bersabda, Apabila amanah telah disia-siakan, maka tunggulah Hari Kiamat. Orang tadi bertanya lagi, Bagaimana bentuk disiasiakannya (Wahai Rasulullah!)? Beliau menjawab, Apabila urusan diserahkan kepada selain ahlinya, maka tunggulah Hari Kiamat" (HR. Bukhari).

Hadits diatas menarik dicermati karena menghubungkan antara amanah dengan keahlian. Hadits ini memberikan peringatan yang bagi yang menjalankan tugas manajerial karena amanah berarti menyerahkan suatu perkara kepada seseorang yang memiliki kompetensi sesuai dengan

\footnotetext{
${ }^{37}$ Hamka, Tafsir Al-Azhar, (Jakarta, Pustaka PanjiMas, 1983),. 125

${ }^{38}$ Ibid, 125
} 
keahliannya. Selain itu kata fantadzir al-sha'ah diucapkan sebanyak dua kali sebagai pertanda betapa pentingnya keahlian atau profesionalisme sesorang. Implikasinya, hadits tersebut mendidik seseorang agar mengedepankan pertimbangan professional dalam menentukan pagawai yang diamanahi suatu pekerjaan atau tanggung jawab, terlebih dalam perkara yang menyangkut persoalan orang banyak.

\section{c. Penggeraakkan (actuating)}

Dalam ilmu manajemen terdapat beberapa istlah yang mempunyai pengertian yang sama dengan actuating. Istilah tersebut adalah motivating yaitu usaha memberikan motivasi kepada seseorang agar mau melaksanakan pekerjaan. Directing yaitu menunjukan orang lain agar mau melaksanakannya, staffing yaitu menempatkan seseorang pada suatu pekerjaan agar orang yang bersangkutan mau mengerjakan perbuatan yang menjadi tanggung jawabnya dan leading yaitu memberikan bimbingan dan arahan kepada seseorang sehingga orang tersebut mau melakukan pekerjaan tertentu. Dalam penggerakkan ada beberapa prinsip yang perlu diperhatikan antara lain: keteladanan, konsistensi, keterbukaan, kelembutan dan kebijaksanaan. Semua prinsip tersebut mempercepat peningkatan kualitas pendidikan. Oleh karena itu, maka dalam menjalankan fungsi actuating termasuk pengarahan (directing) dalam sebuah manajemen dapaat dilakukan dengan cara meningkatkan koordinasi yang baik sesuai dengan kewenangannya yang ada.

Pada wilayah pendidikan, penggerakkan merupakan suatu upaya untuk memberikan arahan dan bimbingan serta dorongan kepada seluruh sumber daya manusia dari semua personil kependidikan agar dapat menjalanya tugasnya dengan kesadaran yang paling tinggi. Dengan demikian penggerakkan yang paling tinggi dilakukan dalam suatu organisasi termasuk pada lembaga pendidikan harus didasarkan pada sifat religious yang tinggi dibarengi dengan keihlasan. Dari sifat ikhlas akan menentukan kebaikan dan hasil yang baik. Sebagaimana Allah SWT berfirman dalam surah al-Bayyinah ayat 5 dan surah al-Kaahfi ayat 2 sebagai berikut:

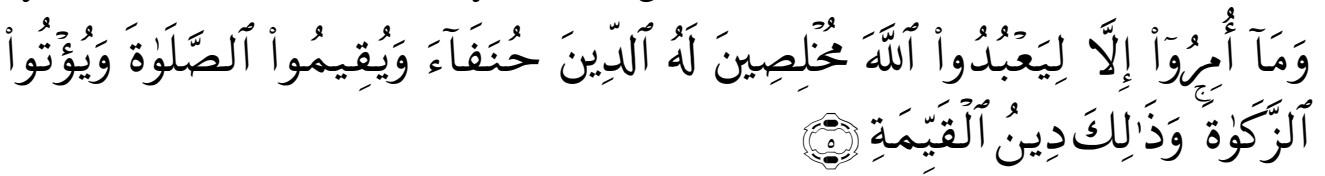

"Padahal mereka tidak disuruh kecuali supaya menyembah Allah dengan memurnikan ketaatan kepada-Nya dalam (menjalankan) agama yang lurus dan supaya mereka mendirikan shalat dan menunaikan zakat; dan yang demikian Itulah agama yang lurus". 


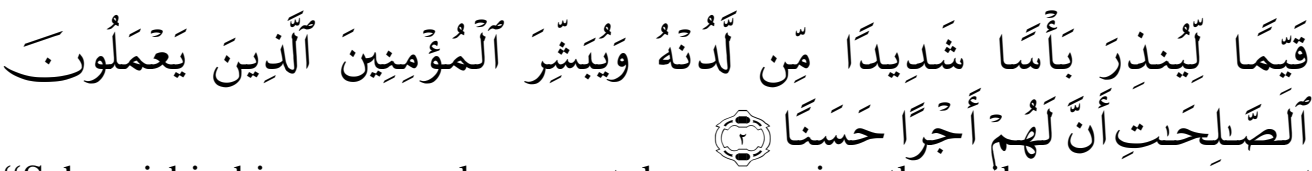

"Sebagai bimbingan yang lurus, untuk memperingatkan siksaan yang sangat pedih dari sisi Allah dan memberi berita gembira kepada orang-orang yang beriman, yang mengerjakan amal saleh, bahwa mereka akan mendapat pembalasan yang baik".

Dengan demikian penggerakkan dalam system manajemen pendidikan adalah dorongan yang didasari oleh prinsip-prinssip religious kepada orang lain, sehingga orang tersebut mau melakukan tugasnya dengan sungguhsungguh dan bersemangat.

\section{d. Pengawasan (controlling)}

Pengawasan adalah keseluruhan upaya pengamatan pelaksanaan kegiatan operasional guna menjamin bahwa kegiatan tersebut sesuai dengan rencana yang telah ditetapkan sebelunya. Dalam pendidikan pengawasan didefinisikan sebagai proses pemantauan yang terus menerus untuk menjamin terlaksananya perencanaan secara konsekwen baik bersifat materil maupun spiritual. Pengawasan dalam sub system pendidikan, baik pada proses kegiatan pembelajaran maupun tata kelola administrasi manajemen pendidikan harus diarahkan kepada upaya memantau secara keseluruhan bahwa dasar perbuatan itu semuanya merupakan tanggung jawab bersama. Rasa memiliki dan bekerja sama untuk menghasilkan kebaikan merupakan sikap positif. Secara keseluruhan bahwa Allah SWT selalu mengawasi semua perbuatan manusia. Berkaitan dengan Penjagaan Allah SWT., Allah berfirman dalam surat arRa'du ayat 11 sebagai berikut:

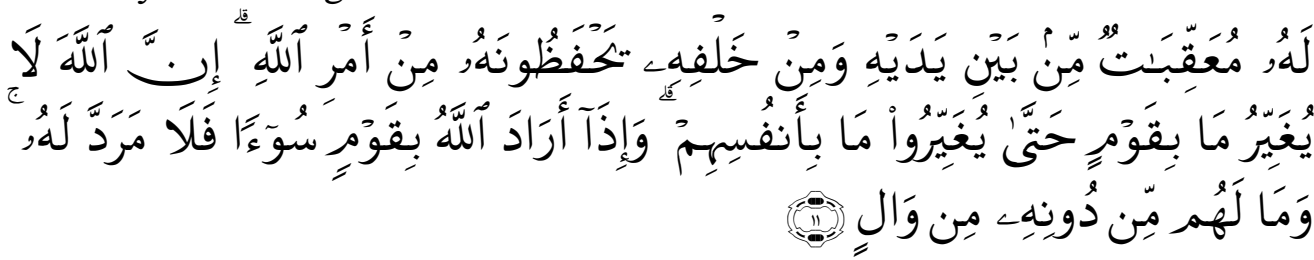

"Bagi manusia ada malaikat-malaikat yang selalu mengikutinya bergiliran, di muka dan di belakangnya, mereka menjaganya atas perintah Allah. Sesungguhnya Allah tidak merobah Keadaan sesuatu kaum sehingga mereka merobah keadaan yang ada pada diri mereka sendiri. dan apabila Allah menghendaki keburukan terhadap sesuatu kaum, Maka tak ada yang dapat menolaknya; dan sekali-kali tak ada pelindung bagi mereka selain Dia".

Makna hâfizh yang lain, adalah bahwa setiap manusia memiliki pengawas yang selalu mengawasi setiap gerak langkahnya, bahkan gerak hatinya sekalipun. Tidak ada satupun yang bisa luput dari pantauan Allah swt, karena 
Allah swt menciptakan banyak pengawas untuk mencatat setiap aktifitas manusia. Hal itu disebutkan Allah swt dalam surat al-Infithar ayat: 10-12.

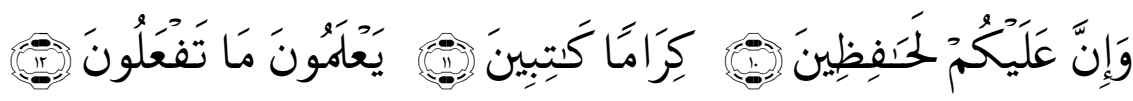

"Padahal Sesungguhnya bagi kamu ada (malaikat-malaikat) yang mengawasi (pekerjaanmu). Yang mulia (di sisi Allah) dan mencatat (pekerjaanpekerjaanmu itu). Mereka mengetahui apa yang kamu kerjakan”.

Dengan demikian, berdasarkan ayat diatas bahwa kegiatan pengawasan dan pemantauan adalah merupakan proses kegiatan untuk mengetahui hasil pelaksanaan untuk diperbaiki dan mencegah terulang kembali kesalahan sehingga pelaksanaan kegiatan pendidikan sesuai dengan rencana yang telah ditetapkan.

\section{Penutup}

Dari penjelasan di atas, dapat disimpulkan bahwa manajemen pendidikan aadalah proses pemanfaatan semua sumber daya yang dimiliki (umat Islam, lembaga pendidikan Islam atau lainnya) baik perangkat keras maupun lunak. Pemanfaatan tersebut dilakukan melalui kerjasama dengan orang lain secara efektif, efisien dan produktif untuk mencapai kebahagiaan dan kesejahteraan didunia dan diakhirat. Terdapat beberapa ayat al-Qur'an yang memberikan isyarat berkenaan dengan manajemen pendidikan. Diantaranya ayat yang mengungkapkan tentang pergantian siang dan malam, pengaturan hujan, pergerakan angin yang diatur dengan sempurna sebagai kebutuhan makhluknya. Hal tersebut menandakan bahwa Allah SWT sebagai pencipta sekaligus mengatur yang memberi manfaat yang baik kepada makhluk-Nya. Pada ayat yang lain terdapat ungkapan dabbara-yudabbiru yang artinya mengatur segala urusan. Apabila dikaitkan dengan manajemen sebagai bidang kajian dalam mengatur tata kerja pada lembaga pendidikan maka, fungsi-fungsi manajemen menjadi alat untuk menjadikan lembaga pendidikan dapat dikelola dengan baik dan terukur. Diantara fungsi-fungsi yang dimaksud adalah diantaranya adalah fungsi perencanaan, pengorganisasian, penggerakan, pengarahan dan pengawasan. Apabila para manajer dalam pendidikan telah mampu melaksanakan tugasnya dengan tepat sesuai dengan fungsi manajemen di atas, maka tidak aka ada lagi lembaga pendidikan khususnya lembaga pendidikan Islam yang ketinggalan zaman, tidak terorganisir dengan rapi dan tentunya akan mampu berjalan dengan baik dan sempurna. 


\section{DAFTAR PUSTAKA}

Ali, Atabik Dan A Zuhdi Mudhlor. Kamus Kontemporer Arab-Indonesia. Yogyakarta, Multi Karya Grafika, 1986.

At-Thibrisi, Abi Ali Fadhli Bin Hasan. Majmu'ul Bayan Fi Tafsir Al-Qur'an, Juz 9. Dar El-Marefah.

Ath-Thuwwairuqi, Nawwal. al-Alaqaat Al-Insaniyah Fi As-Sirah an-Nabawiyah Wa Thathbiiqaatuha Fi al-Idaarah al-Madrasiyah, diterjemahkan oleh Asmunir, Sekolah Unggulan Berbasis Sirah Nabawiyah. Jakarta, Darul Falah, 2004.

Al-Qurthubi, Abu Abdullah Muhammad Bin Ahmad Al-Anshari. Al-Jami' Al-Ahkam Al-Qur'an. Beirut, Darul Al-Kitab Al-Islamiyah, 1995.

Ash-Shiddiqy. Teungku Muhammad Hasbi, Tafsir Al-Qur'anul Majid. Semarang, Pustaka Rizki Putra, 1995.

As-Shabuni, Muhammad Ali. Shafwat At-Tafsir. Beirut, Dar El-Fikri.

Dahlan, Dasrizal Dan Jusmawati. Administrasi Dan Manajemen Perspektif Islam. Padang, The Minangkabau Foundation, 2006.

E. Mulyasa. Manajemen Berbasis Sekolah: Konsep, Strategis Dan Implementasi. Jakarta, Rosda Karya, 2003.

Hakim, Rosniati. Manajemen Guru MDA Dan Implikasinya Terhadap Peningkatan Kualitas Pembelajaran. Padang, Imam Bonjol Press, 2013.

Hamka. Tafsir Al-Azhar. Jakarta, Pustaka PanjiMas, 1983.

Kartono, Kartini. Pemimpin Dan Kepemimpinan. Jakarta, RajaGrafindo Persada, 1998.

M. Echols, Jhon Dan Hasan Shadily. Kamus Inggris-Indonesia. Jakarta, Gramedia, 1993.

Nata, Abudin. Pendidikan Dalam Perspektif Al-Qur'an. Jakarta, Proyek Pengadaan Buku Daras UIN Syarif Hidayatullah, 2005.

Pidarta, Made. Manajemen Pendidikan Indonesia. Jakarta, Rineka Cipta, 2004.

Ramayulis. Ilmu Pendidikan Islam. Jakarta, Kalam Mulia, 2002.

Rahman, Afzalur. Qur'anic Science, Diterjemahkan oleh Arifin, Al-Qur'an Sumber Ilmu Pengetahuan. Jakarta, Rineka Cipta, 2000.

Shihab, M. Quraish. Mukjizat al-Qur'an: Ditinjau Dari Aspek Kebahasaan Dan Pemberitaan Ghaib. Jakarta, Mizan, 1998.

Shihab, M. Quraish. Tafsir Al-Misbah: Pesan, Kesan Dan Keserasian Al-Qur'an, Jilid 7. Jakarta, Lentera Hati, 2002.

Shihab, M. Quraish. Tafsir Al-Misbah: Pesan, Kesan, Dan Keserasian al-Qur'an, .Jakarta, Lentera Hati, 2004.

Sudirman dkk,. Ilmu Pendidikan. Jakarta, Mutiara, 1986.

Yunus, Yulizar. Pengembangan Administrasi, Manajemen Dan Supervisi Pendidikan Islam. Padang, Grafic Delapab Belas, 2010. 